J. Lake Sci. (湖泊科学) , 2017, 29(4): 923-931

DOI 10. 18307/2017. 0416

(C) 2017 by Journal of Lake Sciences

\title{
鄱阳湖通江水道鱼类空间分布特征及资源量评估"
}

\author{
陈文静 ${ }^{1}$, 贺 刚 $^{1}$, 吴 斌 ${ }^{1}$, 方春林 ${ }^{1}$, 林鹏程 ${ }^{2,3 * *}$ \\ (1: 江西省水产科学研究所, 南昌 330039) \\ (2: 中国科学院水生生物研究所,武汉 430072) \\ (3: 中国科学院水生生物多样性与保护重点实验室,武汉 430072)
}

\begin{abstract}
摘 要: 于 2014 年 9 月 24 至 26 日在鄱阳湖通江水道湖口至屏峰段使用 SIMRAD EY60 回声探测仪对鱼类资源进行水声 学调查. 结果显示, 鄱阳湖通江水道鱼类目标强度平均值为 $-56.4 \pm 6.4 \mathrm{~dB}$, 范围为 $-69.9 \sim-32.1 \mathrm{~dB}$; 估算的平均全长为 7.6 $\mathrm{cm}$, 范围为 $1.2 \sim 98.0 \mathrm{~cm}$; 鱼类资源的平均密度为 $53.7 \mathrm{ind} . / 1000 \mathrm{~m}^{3}$, 范围为 $0 \sim 441.7 \mathrm{ind} . / 1000 \mathrm{~m}^{3}$. 在水平分布上, 鱼类主 要分布在湖口县、鞋山和屏峰附近 3 个水域. 区域 I 和区域 III 的鱼类密度显著高于区域 II 的鱼类密度; 区域 III 的鱼类个 体大小显著小于区域 I 和区域 II. 在垂直分布上,多数鱼类栖息于主河槽的深水区,且大个体更倾向于深水区. 在此基础 上, 利用 ArcGIS 地统计插值方法估算鄱阳湖通江水道湖口至屏峰山水域鱼类总数量约为 $6.2 \times 10^{7} \mathrm{ind}$., 总生物量约 $620 \mathrm{t}$. 结果表明,鄱阳湖通江水道是鱼类重要的栖息地,建议加强该水域的保护,保持鄱阳湖与长江的自然连通.
\end{abstract}

关键词: 鄱阳湖;通江水道;生态通道;水声学;空间分布特征; 鱼类资源量

\section{Spatial distribution and biomass assessment of fish in the channel connecting the Lake Poyang and the Yangtze River}

CHEN Wenjing ${ }^{1}$, HE Gang ${ }^{1}$, WU Bin ${ }^{1}$, FANG Chunlin $^{1} \&$ LIN Pengcheng ${ }^{2,3 * *}$

(1: Fishery Research Institute of Jiangxi Province, Nanchang 330039, P.R.China)

(2: Institute of Hydrobiology, Chinese Academy of Sciences, Wuhan 430072, P.R.China)

(3: Key Laboratory of Aquatic Biodiversity and Conservation, Chinese Academy of Sciences, Wuhan 430072, P.R.China)

\begin{abstract}
Channels between lakes and rivers play a crucial role in maintaining fish population dynamics and their diversity in floodplains. In order to better understand the spatial distribution and the biomass of fish in the channel connecting the Lake Poyang and the Yangtze River, a mobile hydroacoustic survey was conducted in September 2014, using Simrad EY60 split-beam echo sounder $(200 \mathrm{kHz})$. The spatial distribution of fish density and biomass for each cell of the studied region was derived from the spatial interpolation with geostatistics of ArcGIS. The results showed that the mean target strength (TS) in the investigated areas is $-56.4 \pm 6.4 \mathrm{~dB}$ and the mean total length is about $7.6 \mathrm{~cm}$, ranging from 1.2 to $98.0 \mathrm{~cm}$. Average fish density in the channel was 53.7 ind. $/ 1000 \mathrm{~m}^{3}$, ranging from $0-441.7 \mathrm{ind} . / 1000 \mathrm{~m}^{3}$. Horizontally, fish assemblages were unevenly distributed in the investigated areas and concentrated mainly in three areas, that is, the section near Hukou Country, Xieshan and Pingfeng Hill, respectively. The most striking feature in fish density was the concave-shaped distribution in the channel along the water flow direction (from lake to river).The fish size (total length) in the area near Lake Poyang (Area III ) was significantly smaller than that in the waters near Yangtze River (Area I ) and the transition zones ( Area II ). One possible reason for this might be a large number of young-of-the-year fish emerged after spawning period. Fish density increased vertically from the upper layer of the water to the lower layers. Meanwhile, our results supported the generality of the phenomenon of increasing fish size with increasing depth (i.e., bigger-deeper phenomenon). In addition, the total amount of fish biomass in the investigated area was estimated to be $6.2 \times 10^{7}$ ind., up to 620 tons. Our findings suggested the need to enhance the protection for these essential fish habitats. This study also contributes to the knowledge of the current state of fish resources and can be useful for proper resources conservation and effective ecosys-
\end{abstract}

* 江西省科技重大专项 (20114ABG01100-1-02-2) 资助. 2016-06-22 收稿; $2016-10$ - 26 收修改稿. 陈文静 (1965 ) ,女,研究员;E-mail:418215117@qq.com.

** 通信作者; E-mail:linpc@ihb.ac.cn. 
tem management of the floodplain biodiversity.

Keywords: Lake Poyang; connections between lakes and rivers; ecological corridor; hydroacoustics; characteristics of spatial distribution; fish biomass

鄱阳湖是我国最大的淡水湖泊. 充足的水资源和优越的自然环境孕育了鄱阳湖丰富的水生生物资源. 据记载, 鄱阳湖分布有鱼类 136 种,隶属于 12 目 25 科 78 属 ${ }^{[1]}$. 鄱阳湖流域是长江中下游鱼类生存的重要场 所及重要经济鱼类的种质资源库. 近年来, 受过度捕捞、生境破坏、滥采砂砾、环境污染等不合理的人为干 扰 ${ }^{[2-4]}$, 鄱阳湖鱼类资源现状已不容乐观, 主要表现为: 渔获物明显以鲤、鲫、粲、鲇、黄颡鱼属等湖泊定居性 鱼类为主; “四大家鱼” 在渔获物中所占比例较低; 刀鲚等洄游性鱼类非常少见; 渔获量逐年下降, 渔获物趋 于低龄化、小型化 ${ }^{[5-6]}$. 因此在鄱阳湖开展鱼类资源监测, 准确及时地评估鱼类资源的分布特征及其数量是 鄱阳湖鱼类资源保护及可持续利用的基本需求.

在内陆水域,网具捕捞是传统鱼类资源调查的常用方法. 然而随着鱼类资源的不断减少, 为了保护鱼类 资源, 在内陆水域开展全面禁渔的呼声越来越高 ${ }^{[7]}$. 全面禁渔的实施, 将导致传统的调查方法受到制约, 另 一些技术和方法将逐步取代网具捕捞, 成为监测的主要方法, 其中水声学方法日益成为鱼类资源监测与评 估的主要手段. 该方法具有快速高效、调查区域广、不损坏生物资源、能实时掌握鱼类空间分布、准确估算鱼 类密度和资源量等优势 ${ }^{[8]} .21$ 世纪以来, 水声学方法已广泛应用于我国长江中上游、三峡水库及一些内陆湖 泊的鱼类资源监测工作中 ${ }^{[9-17]}$, 但对于鄱阳湖这种大型的吞吐型湖泊, 目前尚未见有关水声学方法的调查研 究报道.

湖口是鄱阳湖唯一的人江口. 鄱阳湖通江水道起始于湖口水域而止于水道末端的新池乡 (今蓼南乡) 水 域, 全长约 $40 \mathrm{~km}^{[18]}$. 已有的研究指出, 鄱阳湖通江水道是多种洄游性鱼类完成生活史过程的重要通道, 具 有重要的生态功能, 对于长江中下游鱼类资源的养护及其多样性维持至关重要 ${ }^{[6,19-20]}$. 在此背景下, 本研究 选取鄱阳湖通江水道作为调查区域, 于 2014 年 9 月采用水声学方法对该水域的鱼类资源进行调查, 分析水 道内鱼类资源的空间分布特征, 估算其资源量, 以期为鄱阳湖通江水道鱼类资源的保护和科学管理提供理 论依据.

\section{1 材料与方法}

\section{1 研究区域}

鄱阳湖通江水道范围为星子县老爷庙至湖口县人长江口, 南北长约 $45 \mathrm{~km}$, 东西宽 $3 \sim 8 \mathrm{~km}$, 人长江口最 窄处仅约 $1 \mathrm{~km}$. 湖底水道高程自南向北逐渐下降, 由海拔 $12 \mathrm{~m}$ 降至湖口约 $1 \mathrm{~m}$, 鞋山附近为 $-1 \mathrm{~m}$. 该段人江 水道湖床第四系覆盖层厚度大, 地层分布、岩性特征等基本相同 ${ }^{[18]}$. 本研究中水声学探测范围从湖口码头 $\left(29^{\circ} 44^{\prime} 52.47^{\prime \prime} \mathrm{N}, 116^{\circ} 13^{\prime} 45.49^{\prime \prime} \mathrm{E}\right)$ 至屏峰山 ( $\left.29^{\circ} 31^{\prime} 42.48^{\prime \prime} \mathrm{N}, 116^{\circ} 08^{\prime} 2.06^{\prime \prime} \mathrm{E}\right)$, 探测江段长约 $30 \mathrm{~km}$. 探测水域 的平均水深为 $8.2 \mathrm{~m}$, 最大水深为 $24.5 \mathrm{~m}$, 最小水深为 $3.2 \mathrm{~m}$. 根据河道距离, 将探测范围均分为 3 个水域: 区 域 I、区域 II 和区域 III ( 图 1), 以便于整体分析通江水道鱼类资源的空间格局.

\section{2 水声学调查}

水声学调查设备为 SIMRAD EY60 型分束 (Split-beam) 回声探测仪 (换能器工作频率为 $200 \mathrm{kHz}$, 半功率 角为 $\left.7^{\circ}\right)$. 调查时间为 2014 年 9 月 24-26 日. 由于探测水域地形复杂, 并且有过往的航运船只, 为安全起 见, 探测时间为每天的上午 8 时至下午 6 时. 探测过程中, 换能器固定于监测船的船舷中部, 人水深度为 0.5 $\mathrm{m}$, 波束发射方向垂直向下. 探测路线呈“之”字形, 累计航程 $162.6 \mathrm{~km}$ (图 1). 数据采集过程中, 换能器的发 射功率为 $150 \mathrm{~W}$, 脉冲宽度 (Pulse Duration) 为 $64 \mu \mathrm{s}$. 导航定位设备为 Garmin 60CS 型 GPS. 利用 Latitude E6430 型笔记本电脑对声学数据和 GPS 数据同步存储.

按照 Aglen ${ }^{[21]}$ 覆盖率公式计算水声学调查的覆盖率:

$$
D \mathrm{c}=L / \sqrt{A}
$$

式中, $L$ 为水声学调查走航航程 $(\mathrm{m}), A$ 为探测水域水面面积 $\left(\mathrm{m}^{2}\right), D \mathrm{c}$ 为水声学调查覆盖率. 经计算, 本研究 的声学覆盖率为 13.1 , 达到了 6 以上. 为消除不同介质条件对换能器的影响, 确保回波强度的准确, 在探测 
之前按照设备的出厂说明,采用直径为 $13.7 \mathrm{~mm}$ 的铇铜金属球对仪器进行实地校准 ${ }^{[22-23]}$.

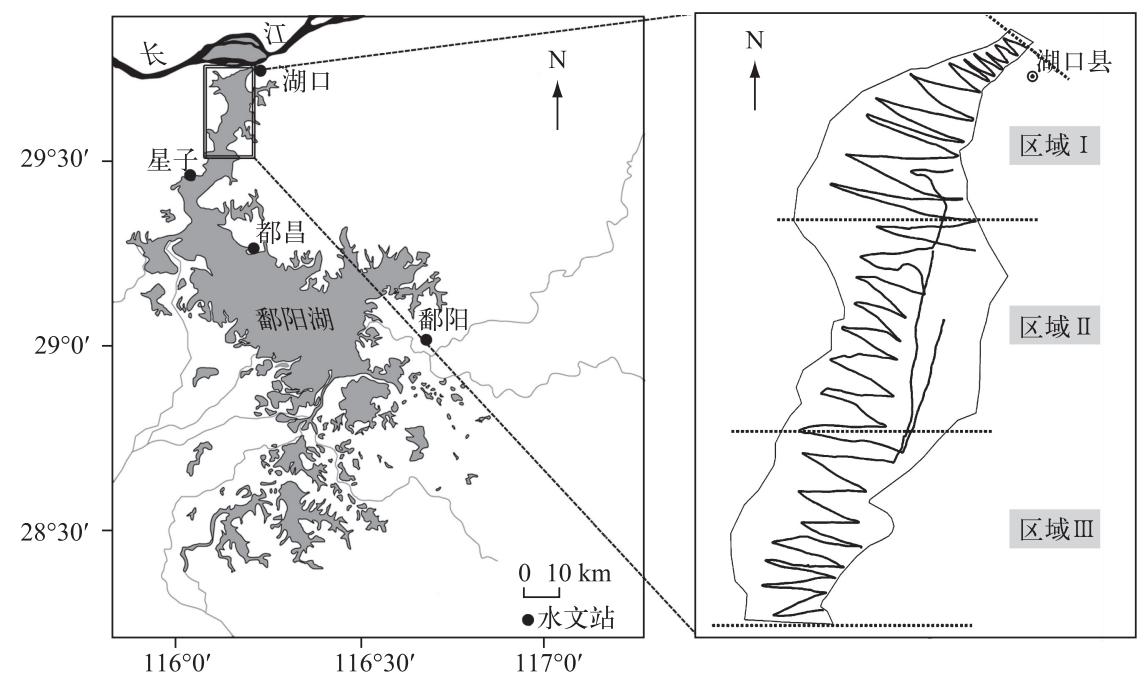

图 1 鄱阳湖通江水道水声学探测区域及航线

Fig.1 The detection area and routes of hydroacoustic survey in the channel connecting Lake Poyang and the Yangtze River

\section{3 数据分析}

1.3.1 声学数据处理 采用 Sonar-5 分析软件对声学数据进行转换和分析. 回声图像使用 CFT( Cross-filter tracking) 方法进行滤波与平滑, 有效消除噪音干扰并准确地提取信噪比比较低的信号. 采用单回波检测与跟 踪分析 (STM) 方法进行信号判别与目标强度 $(T S)$. 声学数据分析的基本积分航程单元设为 $750 \mathrm{~m}$. 声呐数 据处理的相关参数分别为: 单回声检波 (SED) 回波阈值为 $-70 \mathrm{~dB}$; 最小回波长度为 0.8 ; 最大回波长度为 2.0 ; 最大相差为 1.2 ; 声学截面的最大增益补偿为 $6 \mathrm{~dB}$; 时变增益 (TVG) 为 $40 \operatorname{lgR}$; 最少单体目标数为 3 pings; 最 少脉冲数为 3 pings; 单体目标间最大间隔为 2 pings. 最后对提取的鱼类回声信号进行人工检视以保证数据 的准确性.

鱼体长度由 Foote ${ }^{[22]}$ 提出的鱼体目标强度 $(T S, \mathrm{~dB})$ 和全长 $(T L, \mathrm{~cm})$ 的经验公式换算得出:

$$
T S=20 \lg T L-71.9
$$

1.3.2 鱼类密度估算 采用回声计数法 (即鱼类回声计数结果除以探测水体体积) 估算鄱阳湖通江水道的鱼 类密度 ${ }^{[24-25]}$, 计算公式为:

$$
\begin{gathered}
V=\frac{1}{3} \cdot \pi \cdot \tan \frac{\theta}{2} \cdot\left(R^{3}-r^{3}\right) \\
\rho=N / \sum_{i=p}^{i=1} V_{i}
\end{gathered}
$$

式中, $V$ 为每一个 ping 探测的水体体积 $\left(\mathrm{m}^{3}\right), \theta$ 为回声探测仪的角度 $\left(7^{\circ}\right), R$ 为探测位置的水深, $r$ 为换能器 人水水深 $(\mathrm{m}), \rho$ 为鱼类体积密度 (ind. $/ 1000 \mathrm{~m}^{3}$ ), $N$ 为回声计数得到鱼类回声信号个数, $p$ 为单元总的 ping 数.

1.3.3 基于地统计学的鱼类资源量估算 使用 ArcGIS 9.3 软件进行水下地形和鱼类密度分布的空间分析. 将 计算出的各单元鱼类密度、对应的水深及中心坐标数据导人 ArcGIS 9.3, 采用反距离加权 (IDW) 方法进行栅 格插值运算. 本研究设定栅格大小为 $0.0004^{\circ}$, 约为 $45 \mathrm{~m} \times 35 \mathrm{~m}$. 利用导出的每个栅格的鱼类密度、水深和栅 格面积数据计算得到各栅格的鱼类尾数,最后统计所有栅格的鱼类总尾数,从而获得鱼类的资源总量.

各探测区域鱼类回声信号 $T S$ 值差异性的非参数检验、鱼类密度空间分布的单因素方差分析以及鱼类 密度与分布水深的相关性分析等均采用统计分析软件 SPSS 20.0 进行. 


\section{2 结果与分析}

\section{1 鱼类个体特征}

2014 年 9 月在鄱阳湖通江水道共探测到鱼类信号 12032 个, $T S$ 均值为 $-56.4 \pm 6.4 \mathrm{~dB}$, 最小 $T S$ 值为 $-69.9 \mathrm{~dB}$, 最大 $T S$ 值为 $-32.1 \mathrm{~dB}$. 其中 $T S$ 值介于 $-70 \sim-60 \mathrm{~dB}$ 的个体有 3053 个, 占总体的 $25.4 \% ; T S$ 值介 于 $-60 \sim-55 \mathrm{~dB}$ 的个体有 3509 个, 占总体的 $29.2 \%$; TS 值介于 $-55 \sim-50 \mathrm{~dB}$ 的个体有 3992 个, 占总体的 $33.2 \%, T S$ 值介于 $-50 \sim-45 \mathrm{~dB}$ 的个体有 1225 个, 占总体的 $10.2 \%$; TS 值大于 $-40 \mathrm{~dB}$ 的目标信号共 15 个, 约 占总体的 $0.12 \%$ (图 2a). 可见, 鱼类 $T S$ 值主要集中在 $-60 \sim-50 \mathrm{~dB}$ 之间, 累计占总数的 $62.1 \%$. 鱼类以体型 较小者为主.

根据 Foote 提出的鱼体长度与目标强度关系式, 推算 2014 年 9 月鄱阳湖通江水道鱼类平均全长为 7.6 $\mathrm{cm}$, 范围为 1.2 98.0 cm. 2014 年 9 月通江水道鱼类以全长介于 $10 \sim 15 \mathrm{~cm}$ 的个体为主, 累计占总数的 $79.7 \%$ (图 2b).
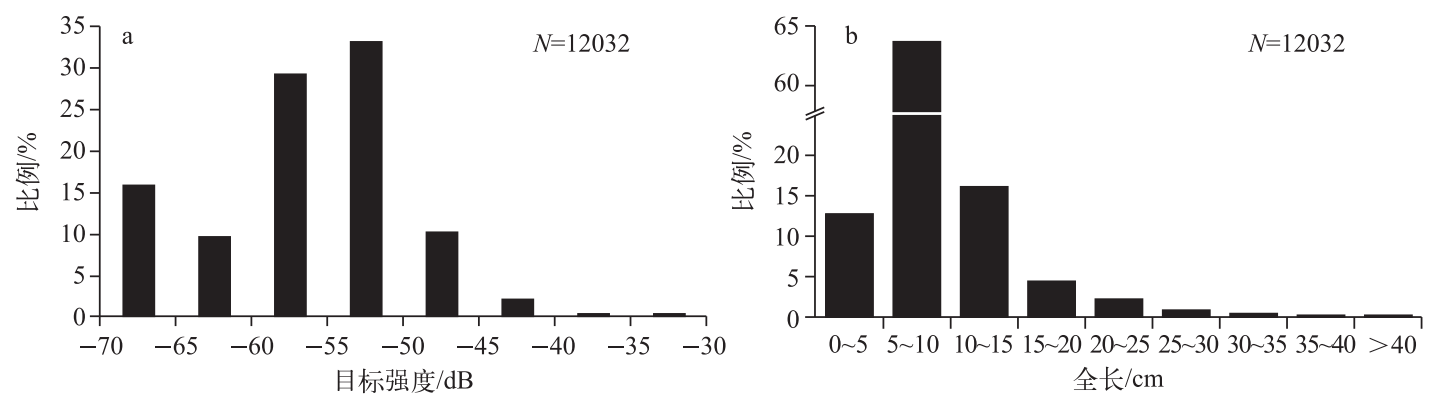

图 2 鄱阳湖通江水道鱼类目标强度 $(\mathrm{a})$ 和全长 $(\mathrm{b})$ 分布

Fig.2 The distribution of target strengths(a) and total length(b) among the observed fish in the channel connecting Lake Poyang and the Yangtze River

\section{2 鱼类密度与空间分布特征}

2014 年 9 月鄱阳湖通江水道鱼类平均密度为 $53.7 \pm 63.2$ ind. $/ 1000 \mathrm{~m}^{3}$, 范围为 $0 \sim 441.7 \mathrm{ind} . / 1000 \mathrm{~m}^{3}$ ( 图 3). 在空间分布上,鱼类主要分布在 3 个水域: (1)湖口县附近通江水域; (2)鞋山附近水域; (3)屏峰山附近水 域. 其中鱼类分布最集中的区域位于鄱阳湖铁路桥至鞋山之间的水域, GPS 中心位点为 $29^{\circ} 41^{\prime} 26.34^{\prime \prime} \mathrm{N}$, $116^{\circ} 10^{\prime} 23.41^{\prime \prime} \mathrm{E}$.

在水平方向, 对 3 个水域的鱼类密度差异进行统计检验. 结果表明, 区域 I (平均密度为 $62.2 \pm$ 63.4 ind. $/ 1000 \mathrm{~m}^{3}$ ) 和区域 III (平均密度为 $72.2 \pm 68.0$ ind. $/ 1000 \mathrm{~m}^{3}$ ) 之间的鱼类密度无显著性差异 ( One-way ANOVA, $P>0.05$ ), 而区域 II (平均密度为 $30.2 \pm 52.3$ ind. $/ 1000 \mathrm{~m}^{3}$ ) 的鱼类密度显著小于区域 I 和区域 III (One-way ANOVA, $P<0.05$ ). 在个体大小方面, 区域 I (平均 $T S$ 值为 $-55.9 \pm 7.0 \mathrm{~dB}$ ) 和区域 II (平均 $T S$ 值为 $-55.8 \pm 5.6 \mathrm{~dB}$ ) 之间的鱼类个体大小无显著性差异 (非参数 K-S 检验, $P>0.05$ ), 而区域 III (平均 $T S$ 值为 $-57.5 \pm 6.5 \mathrm{~dB}$ ) 的鱼类个体大小显著小于区域 I 和区域 II (非参数 K-S 检验, $P<0.05$ ) (图 4).

在水体垂直方向, 将数据分析单元的水深分为 3 层, 水深的 $0 \sim 33 \%$ 为上层, 33\% 66\% 为中层, $66 \%$ $100 \%$ 为下层. 结果显示, $86.9 \%$ 的鱼类栖息于水体下层,平均目标强度为 $-56.0 \pm 5.9 \mathrm{~dB} ; 9.9 \%$ 的鱼类栖息于 水体中层, 平均目标强度为 $-60.0 \pm 6.2 \mathrm{~dB} ; 3.2 \%$ 的鱼类栖息于水体上层, 平均目标强度为 $-60.2 \pm 5.9 \mathrm{~dB}$ (图 $5)$. 回归分析显示, 鱼类数量分布与水深呈显著正相关 $\left(R^{2}=0.651, P<0.01\right)$. 综合可知, 多数鱼类栖息于主 河槽的深水区.且大个体更倾向于深水区. 鄱阳湖通江水道水体下层的生物量高于中上层 (图 6).

\section{3 鄱阳湖通江水道鱼类资源量}

采用 ArcGIS 栅格化的鱼类密度及各个栅格的面积, 对鱼类资源总量进行估算. 鄱阳湖通江水道湖口至 屏峰山水域鱼类资源约为 $6.2 \times 10^{7}$ ind.. 结合多种渔具 (刺网和拖网) 的渔获物调查数据, 该水域鱼类平均体 


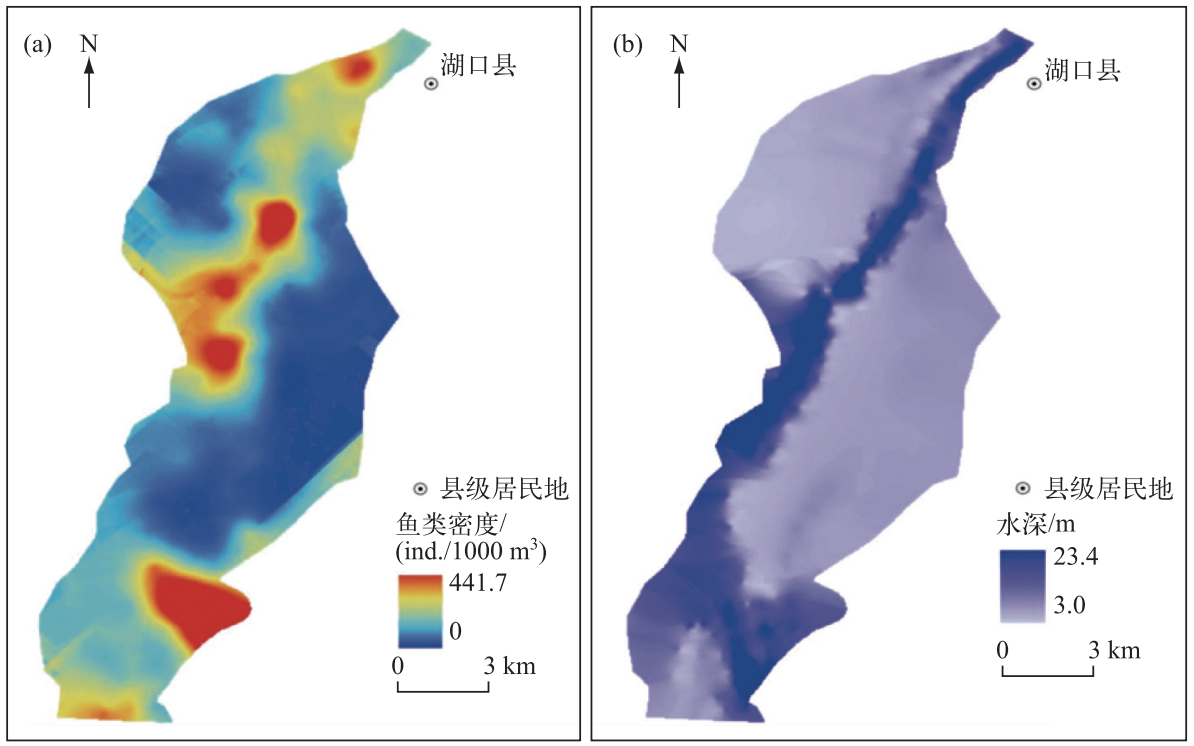

图 3 鄱阳湖通江水道鱼类密度水平分布 $(\mathrm{a})$ 及水深分布 $(\mathrm{b})$

Fig.3 The horizontal distribution of fish density (a) and water depth (b) in the channel connecting Lake Poyang and the Yangtze River
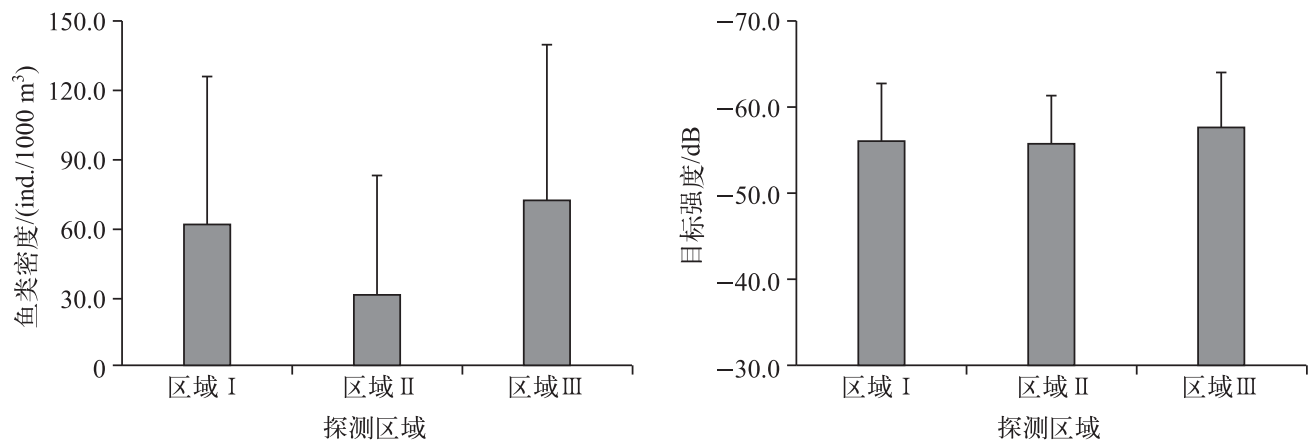

图 4 鄱阳湖通江水道不同水域鱼类密度及目标强度

Fig.4 The fish density and target strengths in different areas in the channel connecting Lake Poyang and the Yangtze River

重约为 $10 \mathrm{~g}^{[15]}$,估算得出鄱阳湖湖口至屏峰山水域的鱼类生物量约为 $620 \mathrm{t}$.

\section{3 讨论}

利用水声学研究鱼类资源是在不扰动水生生物和自然环境的情况下对鱼类分布及集群进行原位观测. 除了能够快速地对整个水体进行探测, 还可实现对水体连续的声学覆盖, 具有较高的分辨率 ${ }^{[8-11]}$. 尽管调查 过程中, 探测任务受到风浪、船体运行等外部环境的影响, 结合研究实践, 认为水声学探测仍是鱼类分布和 资源统计较为全面的方法, 可以准确地给出鱼类大小特征、空间分布和资源量情况, 在调查过程中克服了其 他传统方法工作效率低、难以得到大尺度下的鱼类密度、无法准确获得鱼类自然分布状态下连续数据等局 限性, 获得的数据更有生态学意义.

相关研究指出,鱼类回声信号 TS 值受鱼类大小、脉冲发射频率、鱼类在波束中的位置、游泳行为和河流 


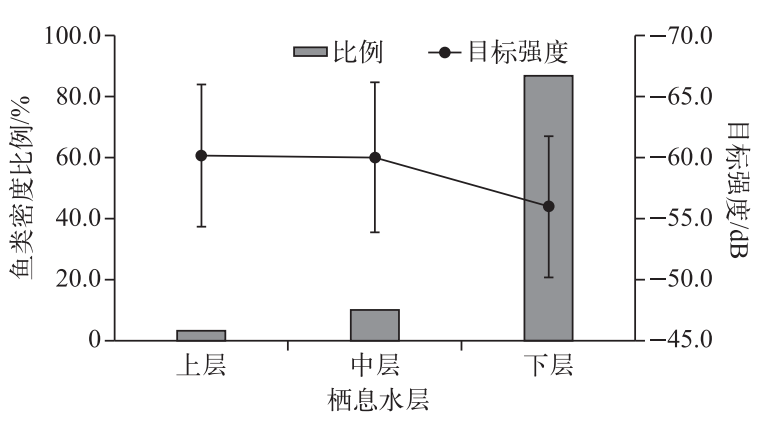

图 5 鄱阳湖通江水道不同水层 鱼类密度及目标强度分布

Fig. 5 The fish density and target strengths in different layers in the channel connecting

Lake Poyang and the Yangtze River

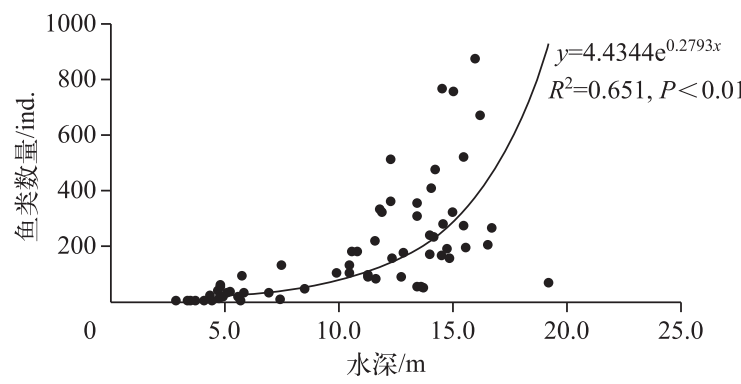

图 6 鄱阳湖通江水道鱼类数量与水深的关系

Fig. 6 Correlation between the fish number and water depth in the channel connecting Lake Poyang and the Yangtze River
环境等因素的影响 ${ }^{[8]}$. 我国淡水水体鱼类多样 性丰富, 目前缺乏特定种类回声信号 TS 值与鱼 体大小关系的系统研究, 各项研究中均无法准确 根据鱼类 TS 值计算出相应的鱼类大小, 对于鱼 类大小的估算需借鉴国外的一些垂直探测的经 验公式 ${ }^{[13-17]}$.

本研究探测到的鱼类回声信号平均 TS 值为 $-56.4 \mathrm{~dB}$, 使用 Foote 提出的 $T S$ 与全长的经验公 式推算出对应的全长为 $7.6 \mathrm{~cm}$. 结果表明, 9 月 鄱阳湖通江水道鱼类个体较小. 而多种网具结合 的渔获物调查显示, 湖口水域秋季主要优势种为 贝氏粲、似鳊、鲤和光泽黄颡鱼等小型鱼类, 尾均 重约 $10 \mathrm{~g}^{[6,20]}$. 因此, 在鱼类个体大小方面, 水声 学调查结果与渔获物调查结果基本一致, 能较好 地反映鱼类个体大小. 推测通江水道鱼类个体较 小的原因主要有: (1)长江中下游水域大多数鱼 类的繁殖时期为 5-7 月. 9 月, 通江水道仍是多 种幼鱼索饵育肥的场所, 故秋季通江水道以体 型较小的鱼类为主; (2)近年来, 随着过度捕捞等 人为原因, 鄱阳湖鱼类资源呈现小型化趋势, 渔 获物结构以当年鱼类为主 ${ }^{[6,26-27]}$.

研究指出, 鱼类时空分布与水深、水温、流 速、河床质及营养化水平等因素有关 ${ }^{[28-31]}$. V a n Nguyen 等 ${ }^{[32]}$ 在研究岩礁鱼类的空间分布时发 现, 水深和离岸距离是影响鱼类水平分布的主 要原因. Marchetti 等 ${ }^{[33]}$ 在研究鱼类集群和栖息 地时发现土著鱼类多分布在流速较高的河段. 杜浩等 ${ }^{[34]}$ 对长江中游江口至涴市江段的鱼类分

布研究也表明鱼类密度分布较高的区域往往是在深水区 (平均水深为 $9.72 \pm 4.18 \mathrm{~m}$ ). 本研究结果表明, 秋季 鄱阳湖通江水道的鱼类分布具有明显的区域性. 空间上,鄱阳湖通江水道的鱼类主要分布在湖口县、鞋山和 屏峰山附近 3 个水域; 在水层分布上,鱼类主要栖息于水体下层,偏好主河槽的深水区. 该结果与多数内陆 水体研究揭示的分布格局一致 ${ }^{[34-36]}$. 究其原因可能有: (1)深水区不仅可提供不同规格个体喜好的环境, 同时 也可提供更多的容纳空间; 2通江水道航运繁忙, 浅水区域鱼类对船只的规避行为要比深水区明显, 这也会 造成主河槽之外水域鱼类密度较低 ${ }^{[35]}$.

生态交错带理论认为, 该区域的一个重要特征就是生境异质性高, 具有较高的生物多样性和生产力. Fernandas 等 ${ }^{[36]}$ 和 Röpke 等 ${ }^{[37]}$ 认为河流交汇有利于提高鱼类多样性. 对于鄱阳湖通江水道而言, 季节性的 洪水淹没,使得河漫滩为鱼类栖息提供丰富的生境. 湖滨带植被及水中的植被为幼鱼或专栖于植被的小型 鱼类提供了庇护所. 在洪泛季节为也可为鲤、鲫等鱼类提供产卵场 ${ }^{[27]}$. 由于汇流口处形成的温度梯度和漩 浴, 营养物质、木质残骸和有机物在此聚集, 有利于浮游动、植物的生长, 进而为鱼类提供了丰富的饵料来 源 $^{[38]}$. 作为连通长江和鄱阳湖的生态通道, 通江水道也可看做是一个生态交错带. 这种江湖时空上的连续 性和生境异质性也是导致鄱阳湖通江水道鱼类密度较高的一个重要原因. 更有学者认为, 像通江水道这样 的生态通道应作为优先保护区加以保护 ${ }^{[37]}$.

本研究首次利用水声学方法对鄱阳湖通江水道鱼类空间分布特征进行研究报道,但是仍存在一定的不 足, 缺乏鱼类分布与上述生态因子的定量关系研究, 有待以后作进一步的研究. 尽管如此, 本研究体现了水 
声学技术在鱼类资源监测研究中优势. 该技术的推广应用可以提高鱼类资源分布和资源量调查的效率,而 且声学数据可以长期保存, 通过数据的累积和对比分析可为揭示江湖鱼类的生态行为规律提供科学依据. 此外, 建议加强对鄱阳湖通江水道的保护, 持续监测水道内鱼类分布及江湖交流活动, 并结合水环境因子, 深人研究该水域鱼类资源的时间动态特征、鱼类群集机制和生境偏好等科学问题, 以期为长江中下游鱼类 资源保护提供科学依据.

\section{4 参考文献}

[ 1 ] Zhang Tanglin, Li Zhongjie. Fish resources and fishery utilization of Lake Poyang. J Lake Sci, 2007, 19(4) : 434-444. DOI : 10.18307/2007.0412. [张堂林, 李钟杰. 鄱阳湖鱼类资源及渔业利用. 湖泊科学, 2007, 19(4) : 434-444.]

[ 2 ] Chen Yiyu, Chang Jianbo. Wetlands loss and alteration of the floodplain in the lower and middle reaches of Yangtze River. In: Chen Yiyu ed. Study of wetlands in China. Changchun: Jilin Science and Technology Press, 1995: 153-160. [ 陈宜 瑜, 常剑波. 长江中下游泛滥平原环境结构改变与湿地丧失. 见: 陈宜瑜编. 中国湿地研究. 长春: 吉林科学技术 出版社, 1995: 153-160.]

[ 3 ] Chang Jianbo, Cao Wenxuan. Fishery significance of the river-communicating lakes and strategies for the management of fish resources. Resources and Environment in the Yangtze Basin, 1999, 8(2) : 153-157. [ 常剑波，曹文宣. 通江湖泊的 渔业意义及其资源管理对策. 长江流域资源与环境, 1999, 8(2)：153-157.]

[ 4 ] Wu Ruijin. Lake water resources and environments in China and countermeasures. Bulletin of the Chinese Academy of Sciences, 2001, 16(3) : 176-181. [ 吴瑞金. 我国湖泊资源环境现状与对策. 中国科学院院刊, 2001, 16(3)：176-181.]

[ 5 ] Huang Xiaoping, Gong Yan. Fishery resources status and conservation in Lake Poyang. Jiangxi Fishery Sciences and Technology, 2007, (4) : 2-6. [ 黄晓平, 龚雁. 鄱阳湖渔业资源现状与养护对策研究. 江西水产科技, 2007, (4) : 2-6.]

[ 6 ] Hu Maolin, Wu Zhiqiang, Liu Yinlan. Fish diversity and community structure in Hukou area of Lake Poyang. J Lake Sci, 2011, 23(2) : 246-250. DOI: 10.18307/2011.0213. [ 胡茂林, 吴志强, 刘引兰. 鄱阳湖湖口水域鱼类群落结构及种 类多样性. 湖泊科学, $2011, \mathbf{2 3}(2): 246-250$. ]

[ 7 ] Tang Qiongying, Li Mingzheng. Fish diversity in Yangtze River and Yangtze River Fishery. Nature, 2014, 2: 8-11. [ 唐琼 英，黎明政. “休渔十年”何时实现一一长江鱼类多样性及长江渔业. 大自然，2014，2: 8-11.]

[ 8 ] Simmonds J, MacLennan DN. Fisheries acoustics: Theory and practice. Oxford: Blackwell Science Ltd, 2005: 437.

[ 9 ] Tao J, Gong Y, Tan X et al. Spatiotemporal patterns of the fish assemblages downstream of the Gezhouba Dam on the Yangtze River. Science China Life Sciences, 2012, 55(7) : 626-636. DOI : 10.1007/s11427-012-4349-0.

[10] Lin PC, Gao X, Zhu QG et al. Hydroacoustic survey on the spatial distribution pattern and day-night rhythmic behaviour of fishes in the Xiaonanhai reach of the upper Yangtze River. Journal of Applied Ichthyology, 2013, 29(6) : 1402-1407. DOI: $10.1111 /$ jai.12342.

[11] Lin PC, Brosse S, Gao X et al. Species composition and temporal pattern of fish passing through the navigation locks in the middle reach of Yangtze River: Implications for fish conservation. Journal of Applied Ichthyology, 2013, 29(6) : 14411444. DOI: $10.1111 /$ jai.12362.

[12] Sun M, Chen DQ, Wang K et al. Hydroacoustic surveys on temporal and spatial distribution of fishes in the section from Chenglingji to Yichang of the Yangtze River middle reaches. Journal of Applied Ichthyology, 2013, 29(6) : 1459-1462. DOI: $10.1111 /$ jai.12368.

[13] Ren Yuqin, Chen Daqing, Liu Shaoping et al. Spatio-temporal distribution of fish in the Pengxi River arm of the Three Gorges reservoir. Acta Ecologica Sinica, 2012, 32(6) : 1734-1744. DOI: 10.5846/stxb201103010249. [任玉芹,陈大 庆,刘绍平等. 三峡库区澎溪河鱼类时空分布特征的水声学研究. 生态学报, 2012, 32(6) : 1734-1744.]

[14] Lian Yuxi, Huang Geng, Godlewska M et al. Hydroacoustic assessment of spatial-temporal distribution and abundance of fish resources in the Xiangxi River. Acta Hydrobiologica Sinica, 2015, 39(5) : 920-929. DOI: 10.7541/2015.121. [连玉 喜,黄耿,Godlewska M 等. 基于水声学探测的香溪河鱼类资源时空分布特征评估. 水生生物学报, 2015, 39(5): 920-929.]

[15] Mou Hongmin, Yao Junjie, Ni Chaohui et al. Hydroacoustic survey of fish resource and spatial distribution in Hongfeng Lake. South China Fisheries Science, 2012, 8(4) : 62-69. [牟洪民, 姚俊杰, 倪朝辉等. 红枫湖鱼类资源及空间分布 的水声学调查研究. 南方水产科学, 2012, 8(4) : 62-69.] 
[16] Sun Mingbo, Gu Xiaohong, Zeng Qingfei et al. Ecological monitoring of the fish resources catching and stocking in Lake Tianmu basing on the hydroacoustic method. Acta Ecologica Sinica, 2013, 33 ( 23 ) : 7553-7562. DOI: 10. 5846/ stxb201209071265. [孙明波, 谷孝鸿, 曾庆飞等. 基于水声学方法的天目湖鱼类资源捕捞与放流的生态监测. 生态 学报, 2013, 33(23): 7553-7562.]

[17] Sun Mingbo, Gu Xiaohong, Zeng Qingfei et al. Hydroacoustic assessment of fish resources in reservoirs with different fishery management. Chinese Journal of Applied Ecology, 2013, 24(1): 235-242. [孙明波, 谷孝鸿, 曾庆飞等. 不同渔业 方式水库鱼类资源的水声学评估. 应用生态学报,2013, 24(1): 235-242.]

[18] Editorial Committee for studies on Lake Poyang ed. Studies on Lake Poyang. Shanghai: Publishing House of Science and Technology, 1988. [ 鄱阳湖研究编委会. 鄱阳湖研究. 上海: 上海科学技术出版社, 1988.]

[19] Li Mingzheng. Study on the life history strategies of fishes in the Yangtze River and its adaption to environment during early life history stage [Dissertation]. Wuhan: Institute of Hydrobiology, CAS, 2012. [黎明政. 长江鱼类生活史对策及其早 期生活史阶段对环境的适应 [学位论文]. 武汉: 中国科学院水生生物研究所, 2012.]

[20] Yang Shaorong, Li Mingzheng, Zhu Qiguang et al. Spatial and temporal variations of fish assemblages in Lake Poyang. Resources and Environment in the Yangtze Basin, 2015, 24(1) : 54-64. DOI: 10.11870/cjlyzyyhj201501008. [杨少荣, 黎 明政, 朱其广等. 鄱阳湖鱼类群落结构及其时空动态. 长江流域资源与环境, 2015, 24(1) : 54-64.]

[21] Aglen A. Random errors of acoustic fish abundance estimates in relation to the survey grid density applied. Norway : Symposium on Fisheries Acoustics, 1983: 293-298.

[22] Foote KG. Fish target strengths for use in echo integrator surveys. Journal of the Acoustical Society of American, $1987, \mathbf{8 2}$ (3) : 981-987.

[23] Balk Helge. Development of hydroacoustic methods for fish detection in shallow water [Dissertation]. Norway: University of Oslo, 2001.

[24] Misund OA. Underwater acoustics in marine fisheries and fisheries research. Reviews in Fish Biology and Fisheries, 1997, 7(1) : 1-34. DOI: $10.1023 / \mathrm{A}: 1018476523423$.

[25] Tao Jiangping, Ai Weiming, Gong Yitian et al. Assessment of fish abundance and distribution using fisheries acoustics and GIS modeling in the Nanxi River of Wenzhou City. Acta Ecologica Sinica, 2010, 30(11): 2992-3000. [ 陶江平, 艾为明, 龚昱田等. 采用渔业声学方法和 GIS 模型对楠溪江鱼类资源量及空间分布的评估. 生态学报, 2010, 30(11): 2992-3000. ]

[26] Hu Maolin, Wu Zhiqiang, Liu Yinlan. Time course of the juvenile major Chinese carps in the Hukou waters of Lake Poyang. Resources and Environment in the Yangtze Basin, 2011, 20(5): 534-539. [胡茂林, 吴志强, 刘引兰. 鄱阳湖湖口 水域四大家鱼幼鱼出现的时间过程. 长江流域资源与环境, 2011, 20(5): 534-539.]

[27] Qian Xin'e, Huang Chungen, Wang Yamin et al. The status quo of fishery resources of Lake Poyang and its environmental monitoring. Acta Hydrobiologica Sinica, 2002, 26(6): 612-617. [钱新娥, 黄春根, 王亚民等. 鄱阳湖渔业资源现状 及其环境监测. 水生生物学报, 2002, 26(6): 612-617.]

[28] Jackson DA, Peres-Neto PR, Olden JD. What controls who is where in freshwater fish communities- the roles of biotic, abiotic, and spatial factors. Canadian Journal of Fisheries and Aquatic Sciences, 2001, 58(1) : 157-170. DOI : 10.1139/ cjfas-58-1-157.

[29] Godlewska M, Swierzowski A. Hydroacoustical parameters of fish in reservoirs with contrasting levels of eutrophication.Aquatic Living Resources, 2003, 16(3) : 167-173. DOI: http://dx.doi.org/10.1016/S0990-7440( 03)00014-7.

[30] Bret V, Bergerot B, Capra H et al. Influence of discharge, hydraulics, water temperature, and dispersal on density synchrony in brown trout populations (Salmotrutta). Canadian Journal of Fisheries and Aquatic Sciences, 2015, 73(3) : 319329. DOI : 10.1139/cjfas-2015-0209.

[31] Zhou L, Zeng L, Fu D et al. Fish density increases from the upper to lower parts of the Pearl River Delta, China, and is influenced by tide, chlorophyll-a, water transparency, and water depth. Aquatic Ecology, 2015, 50(1) : 59-74. DOI: 10. 1007/s10452-015-9549-9.

[32] Van Nguyen L, Phan HK. Distribution and factors influencing on structure of reef fish communities in NhaTrang Bay Marine Protected Area, South-Central Vietnam. Environmental Biology of Fishes, 2008, 82(3) : 309-324. DOI: 10.1007/ s10641-007-9293-7.

[33] Marchetti MP, Moyle PB. Effects of flow regime on fish assemblages in a regulated California stream. Ecological Applica- 
tions, 2001, 11(2) : 530-539. DOI: 10.1890/1051-0761 (2001) 011[0530: EOFROF]2.0.CO;2.

[34] Du Hao, Ban Xuan, Zhang Hui et al. Preliminary observation on preference of fish in natural channel to water velocity and depth: Case study in reach of Yangtze River from Jiangkou Town to Yuanshi Town. Journal of Yangtze River Scientific Research Institute, 2010, 27(10): 70-71. [ 杜浩, 班璇, 张辉等. 天然河道中鱼类对水深、流速选择特性的初步观测. 长 江科学院院报, 2010, 27(10): 70-71.]

[35] Draštík V, Kubečka J. Fish avoidance of acoustic survey boat in shallow waters. Fisheries Research, 2005, 72(2/3) : 219228. DOI: 10.1016/j.fishres.2004.10.017

[36] Fernandas CC, Podos J, Lundberg JC. Amazonian ecology: Tributaries enhance the diversity of electric fishes. Science, 2004, 305(5692) : 1960-1962. DOI: 10.1126/science.1101240.

[37] Röpke CP, Amadio SA, Winemiller KO et al. Seasonal dynamics of the fish assemblage in a floodplain lake at the confluence of the Negro and Amazon Rivers. Journal of Fish Biology, 2015, 89(1) : 194-212. DOI: 10.1111/jfb.12791.

[38] Gayoso AM, Podesta GP. Surface hydrography and phytoplankton of the Brazil-Malvinas currents confluence. Journal of Plankton Research, 1996, 18(6) : 941-951. DOI: 10.1093/plankt/18.6.941. 